the orthodox theory in Turkey to-day, and to prove it, the national emblem of the Crescent shows a star shining through the moon; and Coleridge, in the first draft of "Christabel," is reported to have seated a star in the horns of the crescent.

The sun and moon go round like the hands of a clock, hour and minute, on the old Chaldæan estimate of a year of twelve lunations of thirty days. Full moon would occur when the two hands are in lines directly opposite.

A sundial, marked to serve as a moondial, like the old dial at Queens' College, Cambridge, will give forty-eight minutes added to moonlight time for every day of the moon's age, to give the corresponding sun time on the average.

A moon clock of greater accuracy and variation is required to mark the time when the moon is down longer than usual, drawn down in the legend by Thessalian arts, when the witch loves to ride through the air in the dark.

In "All for Love; or, The World Well Lost," Dryden writes :

Her eyes have power beyond Thessalian charm

To draw the moon from heaven, and this was considered just the time for us to be most on our guard, during the coming winter; although this expectation has not been realised of late.

In ancient astronomical lore as well as in poetry, the sun and moon were pictured as living bodies, and an eclipse could be described as drawing them down to earth, the moon and sun.

Prior information of an eclipse was of great service to counteract superstitious fear, and to claim the magic power as on your own side; as in the case of the solar eclipse predicted by Thales, related by Herodotus, occurring in the middle of an important battle.

A lunar eclipse is so common as to attract little attention to-day; the frequent occurrence compared with a solar eclipse attracted the attention of Aristotle. But the lunar theory involved could be utilised by the Thessalian magician, and would have proved valuable to the Athenian general Nicias in his disastrous retreat from Syracuse.

G. GreenhilL.

\section{THE RESOURCES AND PRODUCTION OF IRON AND OTHER METALLIFEROUS} ORES.

$\mathrm{N}$ order to meet what has apparently been a 1 want both to those engaged in the iron and steel industry and to those who are interested in obtaining knowledge of the mineral resources on which the industry mainly depends, the Advisory Council for Scientific and Industrial Research has thought it desirable that a report ${ }^{2}$ should be compiled summarising the latest information available regarding the iron-ore resources of the United Kingdom, as well as those of other countries. Although a vast amount of information has been published from time to time, it exists

1 Department of Scientific and Industrial Research. Advisory Council. (London: H.M. Stationery Office.) Price 2s. net. NO. 2500 , VOL. IOO] mostly in the form of reports and monographs scattered throughout the Proceedings of technical and scientific societies and in the very valuable publications of the Geological Surveys and Mines Departments of this country and of the principal Dominions of the British Empire; also in those of other countries, particularly the United States. Consequently much time and labour have to be spent in searching for the literature on the subject.

The aim of the report, therefore, has been to collect and present in a summarised form the main facts concerning the resources of iron ores and of other metalliferous ores accessory to the metallurgy of iron and steel, and to indicate their composition and character, giving as many analyses as possible of the minerals in every locality, with indications as to their geographical position and accessibility. The report is the work of Mr. G. C. Lloyd, the secretary of the Iron and Steel Institute, and it has been revised and added to by Prof. Henry Louis, of the Armstrong College, Newcastle-upon-Tyne.

The report is divided into three main parts, of which Part i. deals with the iron ores of Great Britain and Ireland and of the British Dominions. It is known that large resources of iron ores exist in the United Kingdom, but in certain districts, owing to their mode of occurrence, as well as the low percentage of iron which the ores contain, it has been difficult to work some of them profitably. Foreign ores, especially those of Scandinavia, which are of high-grade quality, have been imported so cheaply into this country that the native lean ores could no longer compete with them. Native ores have therefore to a great extent been disregarded, and expenditure upon their development has not been worth while on account of the ease with which cheap supplies of much superior ore could be obtained from abroad. The ores of the United Kingdom are described in approximately the following order:-

(a) Red and brown hæmatites and magnetites (Cumberland, Lancashire, Cornwall, Devonshire, and the Forest of Dean), and the aluminous ores of Co. Antrim, Ireland. These are estimated at about 500 million tons.

(b) Carbonate ores or ironstones (Cleveland, Northamptonshire, Rutlandshire, and Leicestershire), and the calcareous ores of the Lower and Middle Lias (Lincolnshire, Oxfordshire, Wiltshire, and Somerset). Reserves of these are estimated at about 5ooo million tons, but it is thought that probably this figure is too low. Both in Cumberland and Northamptonshire new developments in iron-mining are now taking place on a considerable scale. Some attention has also been lately directed to the Cornish iron ores, but it is extremely doubtful whether these can be worked again upon any important scale.

(c) Stratified iron ores of the Coal Measures (Scotland, Northumberland, Staffordshire, Derbyshire, Shropshire, and South Wales). Reserves of these are estimated at about 34,000 million tons. In normal times by far the largest proportion of the above quantities cannot be worked with profit. 
As regards the production of iron ore, the total amount raised in 1913 was just under 16 million tons, to which Cleveland contributed nearly 6, Northamptonshire 3 , Lincolnshire $2 \cdot 6$, and Cumberland $\mathrm{I} \cdot 3$ million tons. The above total compares unfavourably with the output in 1880 , which was above 18 million tons. Scotland, which then contributed 2.66 million tons, only produced 0.59 million tons in 1913. Staffordshire also shows a big decline. On the other hand, imported ores had risen from 3 million tons in 1880 to 8 million in 1913 , of which 47 came from Spain. Thus some 24 million tons of iron ore were raised and smelted in 1913 , of which slightly above onethird came from abroad. A total of 10.26 million tons of pig iron was produced, representing an average iron content of $42 \cdot 7$ per cent. in the ore.

The resources of the British Dominions are then referred to, the principal deposits at present known being those of Newfoundland, Canada, India, and Australia. Two of the largest iron mines in the world are situated on the northwestern shore of Bell Island, Newfoundland, and from them the Canadian iron industry has drawn its chief ore supplies. Immense resources of iron ore are known to exist in India, but no definite estimate of the quantities available for exploitation has ever been made.

Part ii. gives information of the same kind and so far as it is available with regard to most of the other countries of Europe, Africa, Asia, and North and South America. As regards the ironore deposits of the United States, the economic and industrial conditions render it unlikely that those ores will ever be imported into this country. So far as the iron industry of the United Kingdom is dependent on the iron resources of other countries, any supplies drawn from the United States will probably always be in the form of pig iron or semi-finished and finished iron goods.

In Part iii. notes are given of the principal uses, occurrence, and composition of the ores of metals other than iron but used in the iron industry-viz. chromium, cobalt, manganese, molybdenum, nickel, titanium, tungsten, vanadium, and zirconium, including references to the composition of ferro-alloys manufactured from some of these ores.

\section{THE EFFORTS OF FRENCH INDUSTRY} DURING THE WAR.

WHILE the various Allied countries are busily occupied in discussing elaborate after-war programmes, there is evidence that France at least has passed the domain of mere theoretical speculation. The Société d'Encouragement pour l'Industrie Nationale recently organised at its headquarters in Paris an exhibition of national industries, the exhibits comprising : (a) products manufactured in France since the outbreak of the war, and which prior to the war were all-or nearly all-obtained from abroad; $(b)$ products which before the war were manufactured principally in the regions now in enemy occupation and are now manufactured beyond the French Army zone. A description of the exhibits is given in the JulyAugust number of the society's Bulletin, and the following brief notes refer to the products of a more or less scientific character.

Quartz and Glass Goods.-MM. Adnet and Poulenc Frères exhibited a comprehensive series of glass and quartz vessels used in chemical and bacteriological work, including some specimens of "tuboserum" glass which M. Adnet has manufactured to replace the neutral Jena glass. Other exhibits included Dewar bottles, nitrometers, gas determination apparatus, clinical thermometers, and a microscope the optical and mechanical parts of which were made entirely in France. Special interest attached to the exhibit of a Coolidge tube, which has now assumed importance in connection with the radiography of metals.

Chemistry.-At the outbreak of war France was practically entirely dependent on Germany or on German-owned companies for her supplies of chemicals necessary for the manufacture of high explosives. The war has changed all that, as is evident from the long list of organic compounds shown at the exhibition now under discussion. A comprehensive series of samples of the coaltar derivatives was shown, as well as samples of synthetic nitric acid and nitrates obtained from French works. Again, the French have taken up in earnest the manufacture of pharmaceutical products which were essentially German specialities before the war (aspirin, local anæsthetics, hypnotics, etc.), as the list of exhibits shows. Many compounds used in the manufacture of dyes, varnishes, etc., and in connection with photography and radiology were shown. Progress has also been made in the manufacture of compounds of the rare earths, which in peace time were obtained exclusively from Germany, while pure cerium, ferro-cerium, and magnesium (manufactured for the first time in France) have now passed the experimental stage. Three novelties in the way of chemicals were represented in synthetic acetic acid, synthetic acetic anhydride, and synthetic alcohol.

Miscellaneous.-Ebonite, so largely used in scientific instruments of all kinds-especially electrical - had to be obtained from German firms by France at the outbreak of war. Many samples of ebonite goods were included in the present exhibition, and it is hoped that France may after the war be self-supporting in this respect. The French are also taking up actively (as we are in this country) the manufacture of magnetos, and it is hoped, with the advent of better labour conditions, to replace foreign-made goods by the French article.

It would be highly interesting and instructive from the economic point of view if British manufacturers of articles similar to those described organised a comprehensive exhibit on the lines indicated above. The country would then at least know that serious attempts were being made to take action rather than spend time in abstruse arguments which have little value except for the theoretical economist.

E. S. Hodgson. NO. 2500 , VOL. IOO] 